\title{
First report of Colletotrichum siamense causing anthracnose on banana fruits in Turkey
}

\author{
Aysun Uysal ${ }^{1} \cdot$ Şener Kurt ${ }^{1}$ \\ Received: 9 September 2019 / Accepted: 27 February 2020 / Published online: 16 March 2020 \\ (C) Società Italiana di Patologia Vegetale (S.I.Pa.V.) 2020
}

Keywords Musa acuminata $\cdot$ Anthracnose $\cdot$ Colletotrichum siamense

Banana (Musa acuminata L.) is a desirable crop in Turkey, with a total production of $852,000 \mathrm{t}$ in 2018 . Recently, losses associated with fruit anthracnose were observed on ripening rooms and markets in Hatay province of Turkey. Symptoms included black and sunken lesions with spore masses or acervuli. Anthracnose incidence ranged from 41 to $53 \%$. Three single-spored isolates of Colletotrichum spp. on PDA were first microscopically identified. White to grey coloured cultures having concentric rings of salmon acervuli produced conidia ( 3.5 to $5 \times 10$ to $18 \mu \mathrm{m}$ ) formed in masses, hyaline, and fusiform with obtuse ends. These were consistent with the description of Weir et al. (2012). To confirm morphology, glyceraldehyde-3-phosphate dehydrogenase (GAPDH) gene, a partial sequence of the actin (ACT) gene, and CHS-1 gene of 3 isolates were amplified with the primer pairs GDF1/GDR1, ACT-512F/ ACT-783R, and CHS-79F/CHS-345R, respectively (Weir et al. 2012), and the obtained sequences deposited in GenBank [accession Nos. MF480749, MG951799, MG951810 (isolate BC2); MF480750, MG951800, MG951811 (isolate BC3) and MF480751, MG951801, MG951812 (isolate BC4) for ACT, GAPDH, and CHS-1, respectively]. BLASTn analysis of these se-

Şener Kurt

senerk31040@gmail.com

1 Department of Plant Protection, Faculty of Agriculture, and Centre for Implementation and Research of Plant Health Clinic, Mustafa Kemal University, 31034 Antakya, Hatay, Turkey quences showed a $100 \%$ homology to Colletotrichum siamense strains. For pathogenicity, banana plants (cv. Anamur) were inoculated by spraying with $10 \mu \mathrm{l}$ of a $10^{6}$ conidia per $\mathrm{ml}$ suspension of isolate $\mathrm{BC} 4$ on fruits wounded and disinfested by immersion in $1.5 \% \mathrm{NaOCl}$. Control fruits were treated with sterile distilled water. Fruits were maintained in a moist chamber at $25{ }^{\circ} \mathrm{C}$ with a 12-h photoperiod for 2 days. In $63 \%$ of 30 fruits, anthracnose symptoms appeared between 9 and 15 days later. Control banana fruits remained symptomless. The pathogen has previously been reported from India (Kumar et al. 2017) and Brazil (Vieira et al. 2017). To our knowledge, this is the first report of $C$. siamense causing anthracnose of banana in Turkey.

\section{References}

Kumar VS, Nair BA, Nair PVR, Annamalai A, Jaishanker R, Umamaheswaran K, Sooraj NP, Peethambaran CK (2017) First report of Colletotrichum siamense causing anthracnose of cliff Banana in India. Plant Dis 101(2):390

Vieira WAS, Lima WG, Nascimento ES, Michereff SJ, Câmara MPS, Doyle VP (2017) The impact of phenotypic and molecular data on the inference of Colletotrichum diversity associated with Musa. Mycologia 109(6):912-934

Weir BS, Johnston PR, Damm U (2012) The Colletotrichum gloeosporioides species complex. Stud Mycol 73:115-180

Publisher's note Springer Nature remains neutral with regard to jurisdictional claims in published maps and institutional affiliations. 